\title{
INVOLUCROPYRENIUM BREUSSII \\ (VERRUCARIACEAE, LICHEN-FORMING ASCOMYCOTA), A NEW LICHEN SPECIES FROM CHALK SOIL OF EASTERN UKRAINIAN STEPPES
}

\author{
A. B. Gromakova ${ }^{1}$ and S. Y. KondratyuK ${ }^{2,3}$ \\ ${ }^{1}$ V. N. Karazin Kharkiv National University, Svobody Sq. 4, 61022 Kharkiv, Ukraine \\ E-mail: alla.gromakova@karazin.ua \\ ${ }^{2}$ M. H. Kholodny Institute of Botany, Tereshchenkivska str. 2, 01004 Kyiv-1, Ukraine \\ E-mail:ksya_net@ukr.net \\ ${ }^{3}$ Korean Lichen Research Institute, Sunchon National University \\ Sunchon 540-742, Republic of Korea
}

(Received 27 March, 2017; Accepted 8 May, 2017)

Involucropyrenium breussii A. B. Gromakova et S. Y. Kondr., a new lichen species for science, is described from eastern Ukraine, illustrated and compared with closely related taxa. It is similar to I. tremniacense from which it differs in having smaller thalline areoles, narrower rhizohyphae, a medullary layer differentiated in the centre of areoles, and longer ascospores. A short description of plant communities in which Involucropyrenium breussii was found in Ukrainian steppes with chalk outcrops is provided.

Key words: Involucropyrenium, lichen-forming fungi, new species, Ukraine, Verrucariaceae

\section{INTRODUCTION}

During a special study on lichen diversity of chalk outcrops of Kharkiv oblast, eastern part of Ukraine a number of rare lichen species was found (Gromakova 2012, 2013, 2014, Haji Moniri et al. 2017, Kondratyuk et al. 2015). Among them one pyrenocarpous lichen species of the genus Involucropyrenium was found, which is a new species for science.

The aim of this paper is to provide a formal description of the new species named below as Involucropyrenium breussii.

\section{MATERIAL AND METHODS}

Results of revision are based on numerous specimens from collections deposited in CWU, KW-L, and KoLRI, as well as some specimens from another herbaria included in comparative study. 
Involucropyrenium breussii A. B. Gromakova et S. Y. Kondr., spec. nova (Figs 1-6)

MycoBank number: MB 822414.

Similar to Involucropyrenium tremniacense, but differs in having smaller thalline areoles, narrower rhizohyphae, a medullary tissue differentiated in the centre of areoles, and longer ascospores.

Type: Ukraine, Kharkiv oblast (= region), Dvorichansky district, in the vicinity of Dvorichna settlement, Krejdyanyj [= Chalk] protected territory (= zakaznyk), chalk outcrops in the valley of Oskil river, in the middle part of the gentle slope, on chalk soil. Lat.: $49^{\circ} 49^{\prime} 22.5^{\prime \prime}$ N; Long.: 37 40' 27.9" E; Alt.: $110 \mathrm{~m}$ a.s.l. Coll.: Gromakova, A. B., 21.08.2012 (CWU 200290 - holotype); the same locality (CWU 200293, CWU 200294, CWU 200295, CWU 200296, KW-L - isotypes).

Thallus areolate, mostly consisting of distant, separate areoles and indistinct owing to small measurements of areoles, or areoles more or less densely aggregated in portions to $2-4 \mathrm{~mm}$ diam., often with very uneven portions, light brown to medium brown to greyish brown with somewhat lighter central portion of dense aggregation; areoles $0.1-0.3(-0.5) \mathrm{mm}$, more or less rounded to irregular, to $0.5 \mathrm{~mm}$ long and $0.25 \mathrm{~mm}$ wide if elongated, more often distant each other, especially when young and divided by cracks sometimes, later becoming more or less aggregated, flattened to slightly semiconvex, epruinose, closely appressed to the substratum (often edges covered by dust particles of soil and thus areoles seemingly immersed into the substrate); upper surface lightly to medium greyish-brownish, in the centre somewhat lighter than in peripheral portions. Thallus 80-150(-220) $\mu \mathrm{m}$ thick; upper cortex paraplectenchymatous to 20-35 $\mu \mathrm{m}$ thick, often the upper portion (ca $15 \mu \mathrm{m}$ thick) lightly brownish, while the lower portion hyaline, cell lumina to $5 \mu \mathrm{m}$ across, cell wall to $1 \mu \mathrm{m}$ thick; epinecral layer 12-25 $\mu \mathrm{m}$ thick. Algal layer 50-90 $\mu \mathrm{m}$ thick, algal cells 6-7.2 $\mu \mathrm{m}$ diam. Medulla differentiated only in the centre of areoles, while it is not differentiated at the areole edges (in peripheral portions); lower cortex lacking. Rhizohyphae sparse, hyaline, 2.4-2.6 $\mu \mathrm{m}$ wide.

Perithecia mostly single or rarely aggregated in small groups, mostly developed between the areoles, more or less globose, up to 200-300 $\mu \mathrm{m}$ diam., almost completely immersed into the substratum, only ostiolum and involucrellum seen above substrate surface as black dots to $0.1 \mathrm{~mm}$ diam., and rather indistinct. Involucrellum to $50 \mu \mathrm{m}$ thick, dimidiate, developed only in the upper half of perithecium, appressed to the exciple. Exciple brown to black, to $12-25 \mu \mathrm{m}$ thick, wall composed of tangentially arranged, more or less elongated cells. Periphyses 15-25 × 1-1.5 $\mu \mathrm{m}$. Asci clavate, $50-70 \times 10-15$ $\mu \mathrm{m}, 8$-spored. Ascospores biseriate, ellipsoid, (14-)16.5-19(-20) $\times$ 6-7.5(-8) $\mu \mathrm{m}$ (20 measurements). 
Pycnidia absent.

Chemistry: Thallus $\mathrm{K}-, \mathrm{C}-, \mathrm{KC}-, \mathrm{P}-$; content of perithecium I+ blue then becoming red.
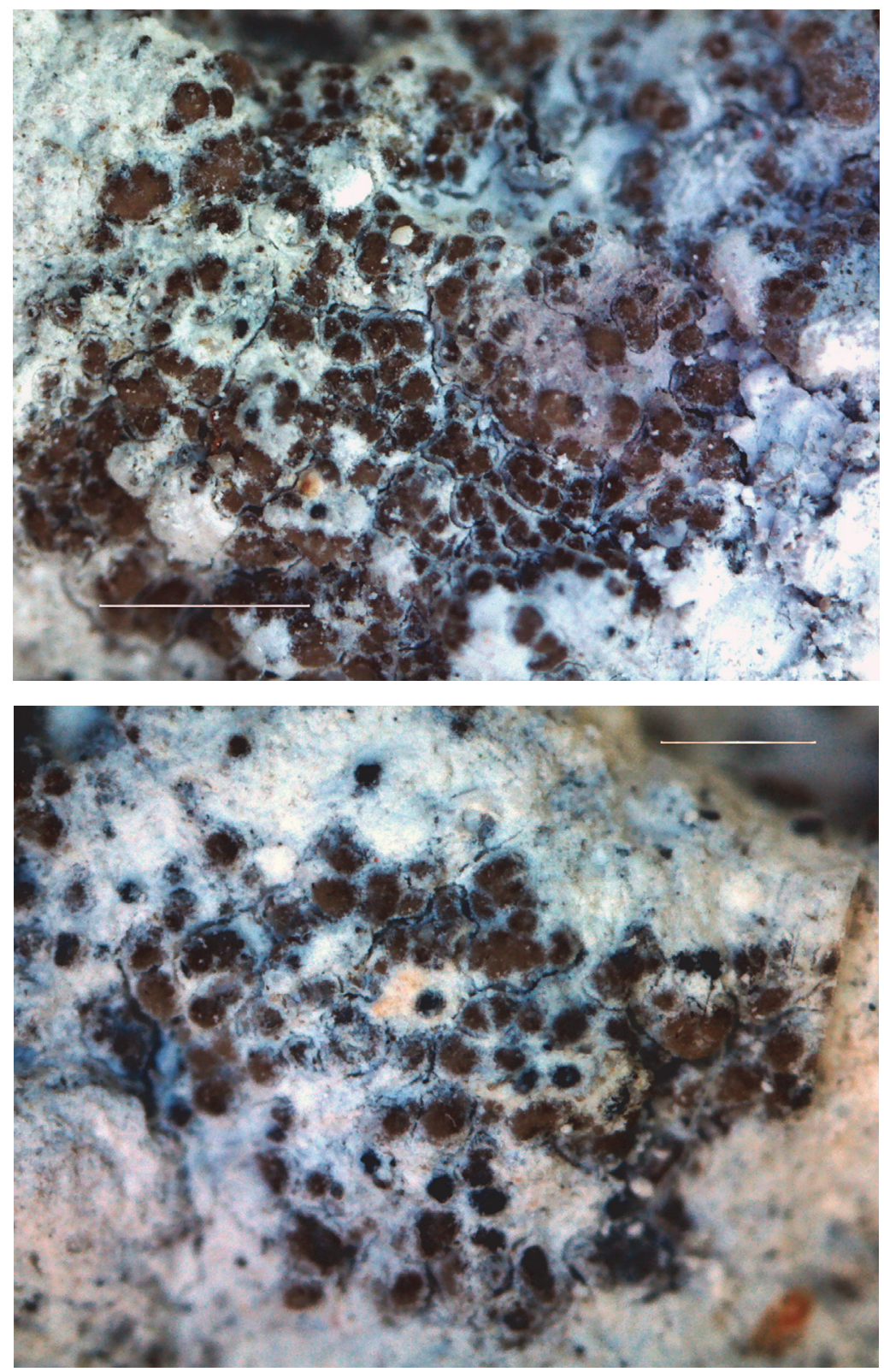

Fig. 1. Involucropyrenium breussii (KW-L - isotype), general habit. Scale $1 \mathrm{~mm}$ (top), and 0.5 $\mathrm{mm}$ (bottom) (photo S. Kondratyuk) 

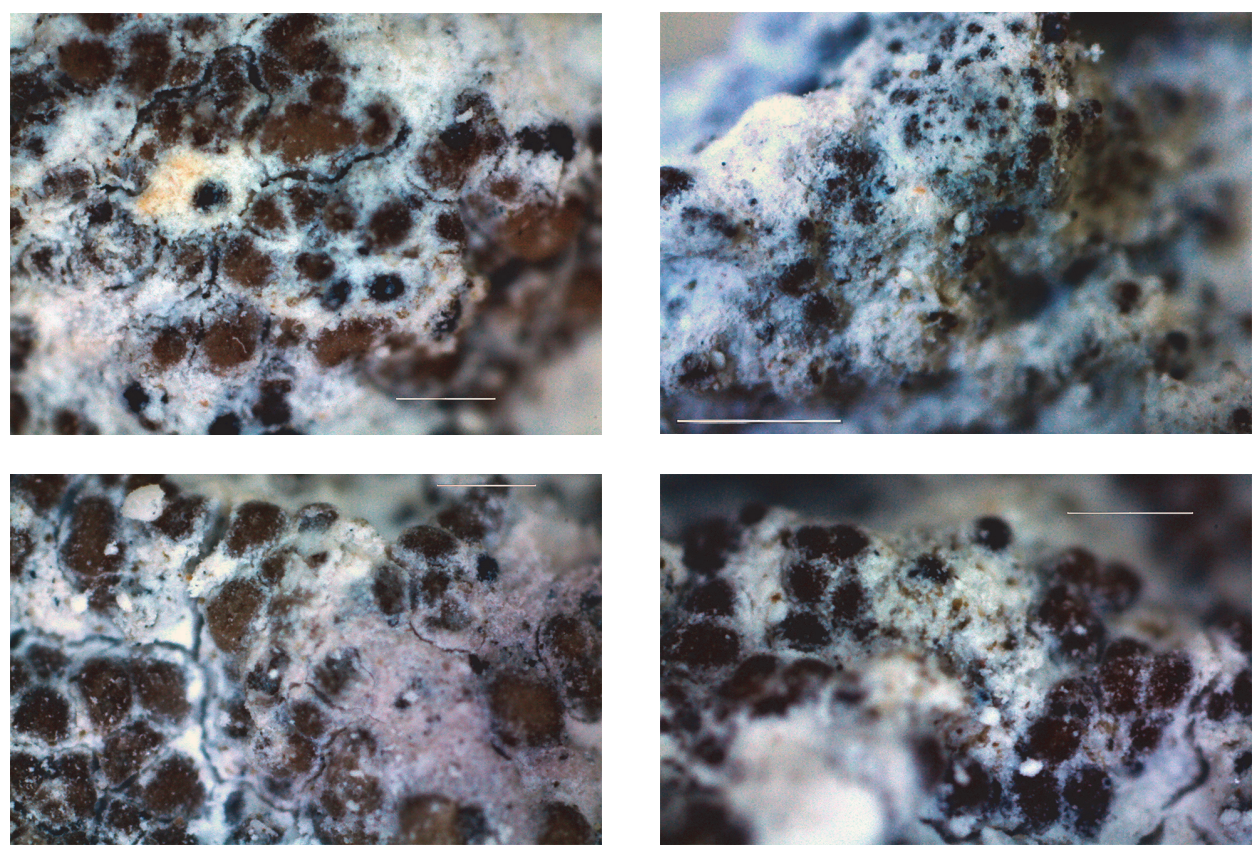

Fig. 2. Involucropyrenium breussii (KW-L - isotype), enlarged portion with thalline areoles and perithecia. Scale $0.5 \mathrm{~mm}$ (photo S. Kondratyuk)

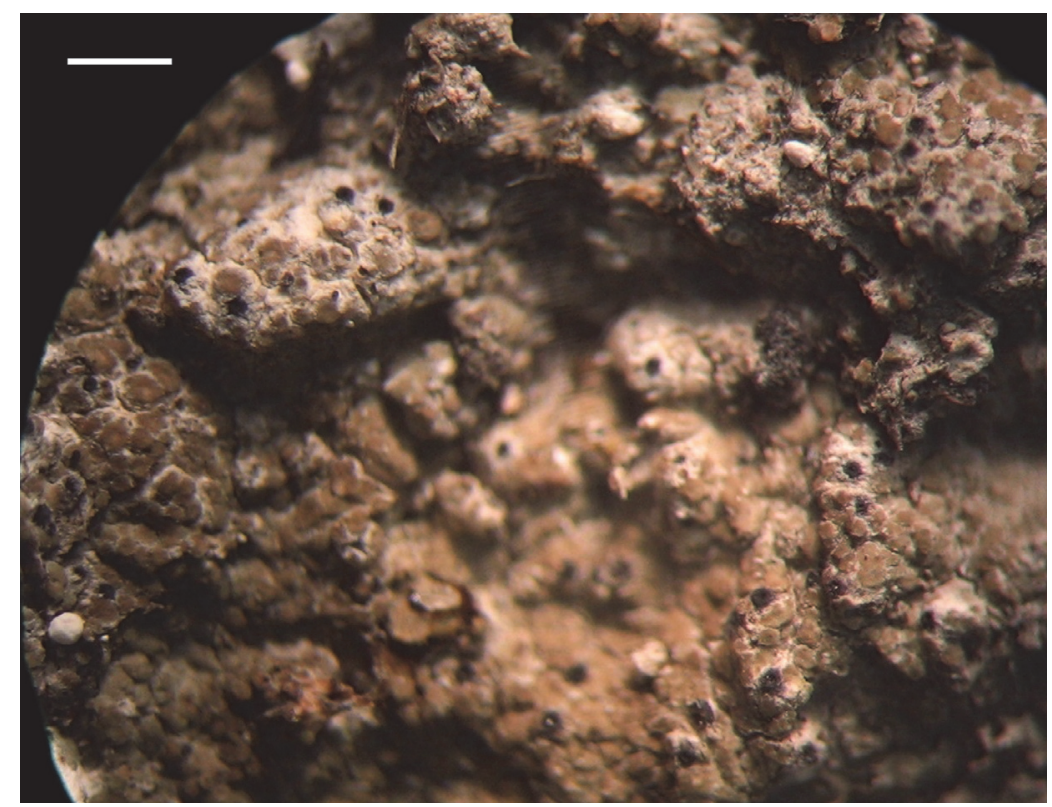

Fig. 3. Involucropyrenium breussii (holotype: CWU 200290), general habit. Scale $1 \mathrm{~mm}$ (photo A. Gromakova) 
Ecology: Involucropyrenium breussii is found in open grassland on hard chalk soil in open dry, semiarid localities of the steppes. The species grows together with Catapyrenium squamulosum (Ach.) Breuss, Endocarpon pusillum Hedw., Enchylium tenax (Sw.) Gray, Scytinium schraderi (Ach.) Otálora, P. M. Jørg. et Wedin, and Megaspora verrucosa (Ach.) Arcadia et A. Nordin on calcareous soil in arid steppe or steppe-like habitats.

Involucropyrenium breussii was collected on gentle slope $\left(\right.$ about $30^{\circ}$ ) of the chalk outcrops, where the total plant cover was also about $15-20 \%$, with Artemisia salsoloides Willd. and Thymus calcareus Klokov et Des.-Shost., as dominant taxa. Rarely as associated taxa the following plants were recorded: Androsace koso-poljanskii Ovcz., Artemisia hololeuca M. Bieb. ex Besser, Asperula cynanchica L., Bupleurum falcatum L., Cephalaria uralensis (Murray) Roem. et Schult., Hyssopus cretaceus Dubjan., Linaria cretacea Fisch. ex Spreng., Linum hirsutum L., Odontites luteus (L.) Clairv., Pimpinella titanophila Woronow, Polygala cretacea Kotov, Scrophularia cretacea Fisch. ex Spreng., Teucrium polium L., and Vincetoxicum hirundinaria Medik.

Distribution: The species so far only found in the chalk slopes of Oskil River and of Verhnya Dvorichna River which is its tributary, in eastern part of Ukrainian Plains, southeastern Europe.

Etymology: Species is named after well-known Austrian lichenologist Othmar Breuss in recognition of his important contribution to our recent knowledges on the Verrucariales and who has described the genus Involucropyrenium (Breuss 1996).
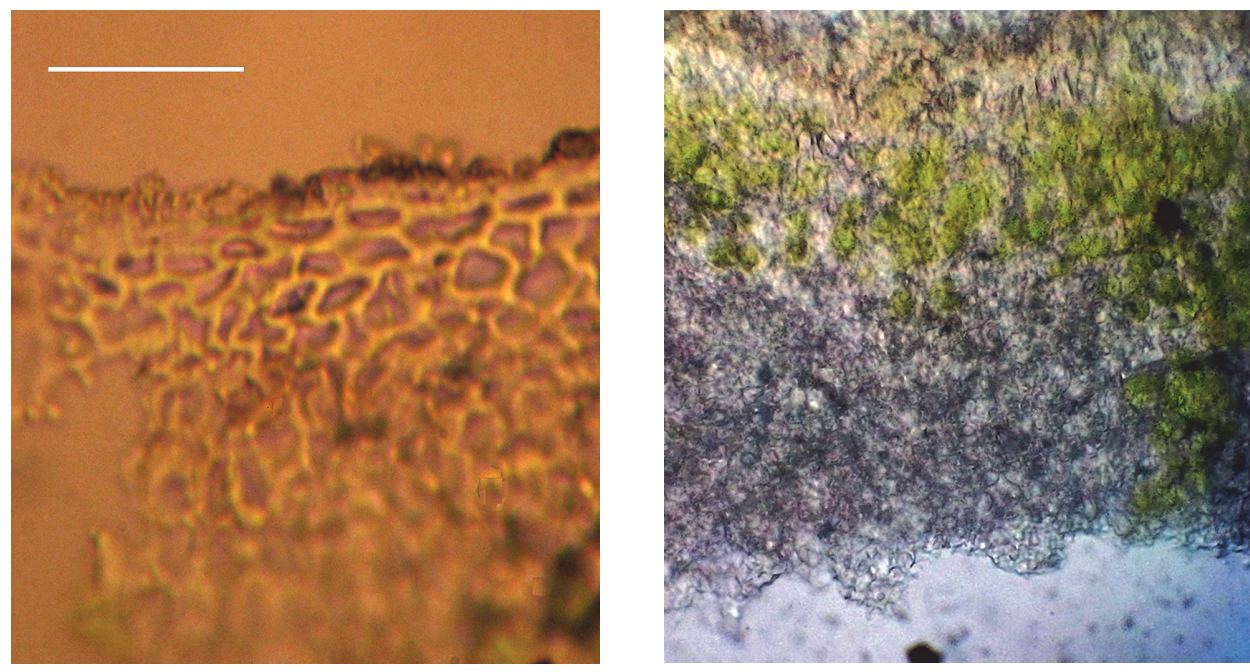

Fig. 4. Involucropyrenium breussii (holotype: CWU 200290), enlarged portion of cortical layer of thallus (left, scale $20 \mu \mathrm{m}$ ) and medulla (right) (photo A. Gromakova) 

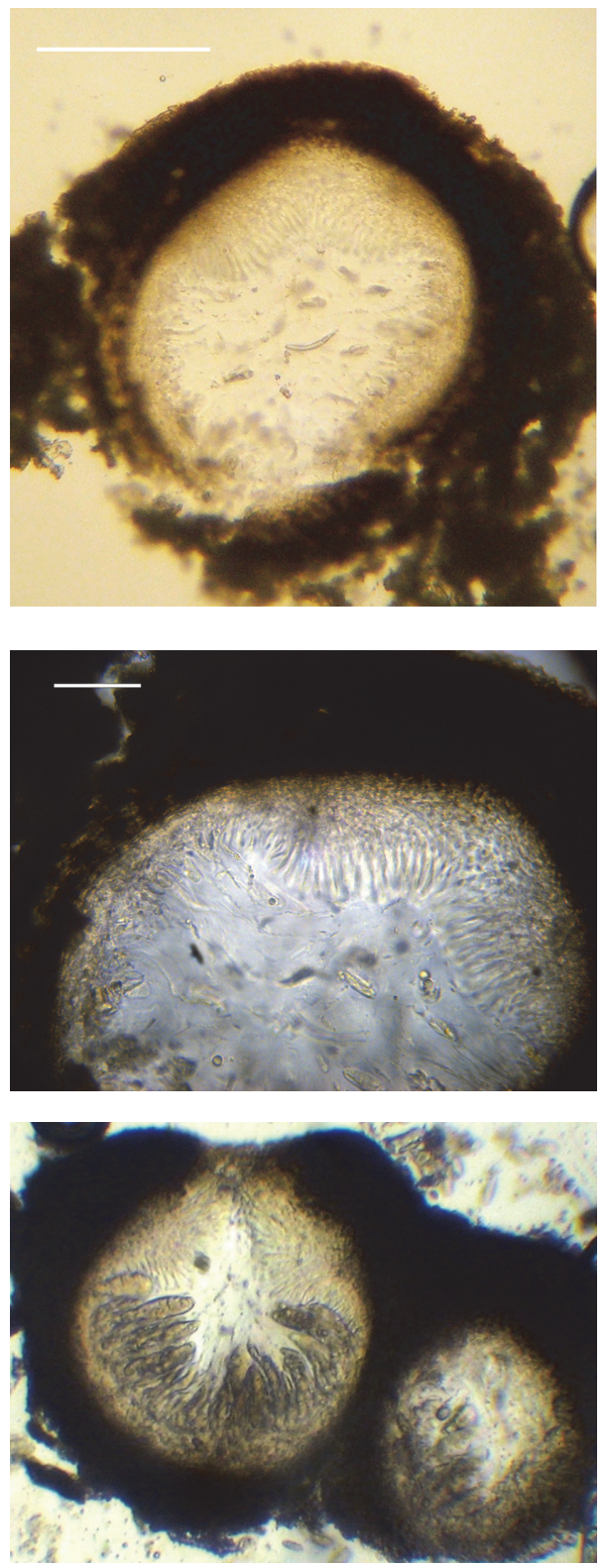

Fig. 5. Involucropyrenium breussii (holotype: CWU 200290), enlarged portion of section of perithecium (top) and exciple (bottom). Scale $100 \mu \mathrm{m}$ (top) and $20 \mu \mathrm{m}$ (bottom) (photo A. Gromakova)
Taxonomic notes: Involucropyrenium breussii is characterised by the combination of dimidiate involucrellum, and thallus of mostly dispersed areoles. It is similar to I. tremniacense (A. Massal.) Breuss, but differs in having smaller thalline areoles (0.1-0.3 (-0.5) mm vs. 0.3-1.5(-2) mm across), in having narrower and sparse rhizohyphae (2.4-2.6 $\mu \mathrm{m}$ vs. ca $4 \mu \mathrm{m}$ thick, pale, forming a dense network (hypothallus)), in having medulla differentiated in the centre of areoles (vs. medulla not differentiated), in having dimidiate involucrellum (vs. shield shaped, apical involucrellum), and in having longer ascospores ((14-)17$19(-20) \times 6-7(-8) \mu \mathrm{m}$ vs. $13-17(-18) \times$ 6-7(-8) $\mu \mathrm{m})$ (Breuss 1990, 1996, 2010).

Involucropyrenium breussii differs from I. waltheri (Kremp.) Breuss in having dimidiate involucrellum, in having colourless rhizohyphae, in having smaller ascospores and in geographic distribution. Involucropyrenium breussii is positioned in somewhat intermediate position between I. waltheri and I. tremniacense (Breuss 1990, 1996, 2010).

Involucropyrenium breussii is similar to I. llimonae (Etayo, Nav.-Ros. et Breuss) Breuss and I. pusillum Breuss et Türk in having hyaline rhizohyphae (Breuss 2010, Breuss and Türk 2004, Navarro-Rosinés et al. 1996, Prieto et al. 2010, 2012). However, I. breussii differs from the latter species in having partial involucrellum (or involucrellum integrum) (i.e.: not enclosing the entire perithecium). Furthermore, in contrast to I. llimonae and I. pusillum 

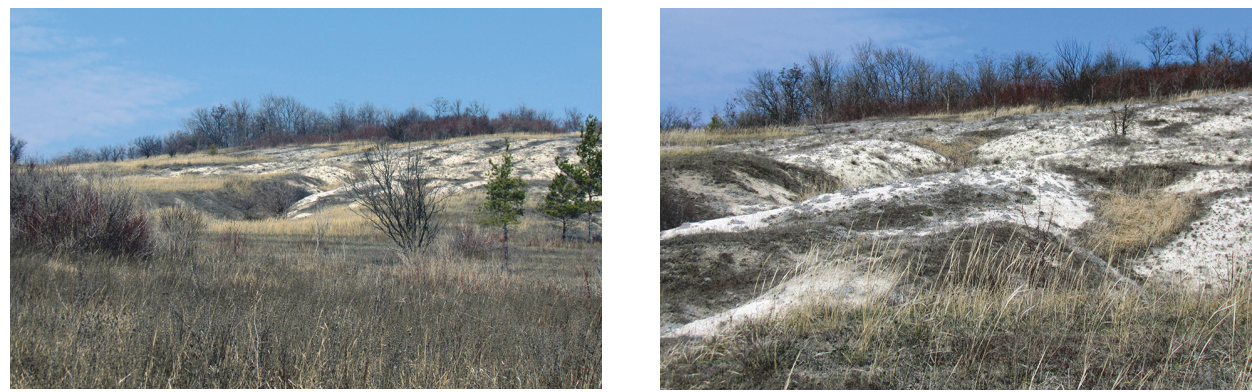

Fig. 6. Type locality of Involucropyrenium breussii in steppes on chalk outcrops (photo V. Kletenkin)

the new species does not form squamules with a very characteristic shape (finely divided to digitate-coralloid), and it has somewhat smaller ascospores. In contrast to I. pusillum, Involucropyrenium breussii does not have thallus of crowded often overlapping squamules, and it has smaller ascospores (Navarro-Rosinés et al. 1996, Prieto et al. 2010, 2012).

Other specimens examined (paratypes): Ukraine, Kharkiv oblast (= region), Dvorichansky district, in the valley of Verhnya river, in the vicinity of Petro-Ivanivka village, on chalk soil. Lat.: $49^{\circ} 55^{\prime} 32.8^{\prime \prime} \mathrm{N}$; Long.: $37^{\circ} 40^{\prime}$ 45.7" E; Alt.: $121 \mathrm{~m}$ a.s.l. Coll.: Gromakova, A. B., 28.05.2012 (CWU 200516); Kharkiv oblast (= region), Dvorichansky district, in the vicinity of Kolodyazne village, on chalk soil. Lat.: $49^{\circ} 59^{\prime} 40.2^{\prime \prime} \mathrm{N}$; Long.: $37^{\circ} 40^{\prime}$ 50.1" E; Alt.: 155 m a.s.l. Coll.: Gromakova, A. B. 28.05.2012 (CWU 200517); Kharkiv oblast, Dvorichansky district, in the vicinity of Dvorichna settlement, Kreidyany [= Chalk] protected territory (= zakaznyk), on chalk soil with Artemisia salsoloides Willd. Lat.: $49^{\circ} 49^{\prime}$ 39.5" N; Long.: $37^{\circ} 40^{\prime} 33.8^{\prime \prime}$ E; Alt.: ca 126 m a.s.l. Coll.: Gromakova, A. B., 18.09.2016 (CWU 200640, KW-L).

\section{CONCLUSIONS}

New for science species, i.e.: Involucropyrenium breussii A. B. Gromakova et S. Y. Kondr., from eastern Ukraine, similar to Involucropyrenium tremniacense, but differing in having smaller thalline areoles, in having hyaline and narrower rhizohyphae, in having medullar differentiated in the centre of areoles, and in having longer ascospores is described. The further clarifying status of Involucropyrenium breussii and other members of the family Verrucariaceae on the basis of molecular data planned to be done in next special paper.

Acknowledgements - We are thankful to Dr Edit Farkas (Vácrátót, Hungary), Dr Othmar Breuss (Wien, Austria), Dr László Lőkös (Budapest, Hungary), and two reviewers for valu- 
able comments on manuscript, and Dr. Yurij G. Gamulya (Kharkiv, Ukraine) for providing data on plant communities, Volodymyr G. Kletenkin (Dvorichna, Ukraine) for providing photos of type locality, as well as to Dr Jae-Seoun Hur (Sunchon, Republic of Korea) for providing facilities for microscopical study and making photos, as well as for providing molecular data for some members of the Verrucariaceae. SK is thankful to Ministry of Education and Science of Ukraine (M/90-2015-285 and M/34-2016-285) and Korean Brain Pool Program (161S-4-3-1659) for financial support.

\section{REFERENCES}

Breuss, O. (1990): Die Flechtengattung Catapyrenium (Verrucariaceae) in Europa. - Stapfia 23: 1-153.

Breuss, O. (1996): Ein verfeinertes Gliederungskonzept für Catapyrenium (lichenisierte Ascomyceten, Verrucariaceae). - Ann. nat.-hist. Mus. Wien. 98 (Suppl.): 35-50.

Breuss, O. and Türk, R. (2004): Involucropyrenium pusillum (Verrucariaceae), eine neue Flechtenart aus Oberösterreich. - Beitr. Naturk. Oberösterr. 13: 213-216.

Breuss, O. (2010): An updated world-wide key to the catapyrenioid lichens (Verrucariaceae). - Herzogia 23: 205-216. https://doi.org/10.13158/heia.23.2.2010.205

Gromakova, A. B. (2012): Lichens of "Volchanskiy" Botanical Reserve (Kharkiv region, Ukraine). - J. V. N. Karazin Kharkiv Nat. Univ., ser. biol. 15(1008): 57-62.

Gromakova, A. B. (2013): New and rare species of lichens for the left-bank part of Ukraine from cretaceous outcrops. - Ukr. Bot. J. 70(5): 664-668.

Gromakova, A. B. (2014): New and rare lichens and lichenicolous fungi for the left-bank part of Ukraine from the Seversky Donets River basin. - Chornomors'k. bot. z. 10(4): 506-514. https://doi.org/10.14255/2308-9628/14.104/5

Haji Moniri, M., Gromakova, A. B., Lőkös, L. and Kondratyuk, S. Y. (2017): New members of the Megasporaceae (Pertusariales, lichen-forming Ascomycota): Megaspora iranica spec. nova and Oxneriaria gen. nova. - Acta Bot. Hung. 59(3-4): 343-370. https:// doi.org/10.1556/abot.59.2017.3-4.5

Kondratyuk, S. Y., Gromakova, A. B., Khodosovtsev, A. Y., Kim, J. A., Kondratiuk, A. S. and Hur, J.-S. (2015): Agrestia zerovii (Megasporaceae, lichen-forming Ascomycetes), a new species from southeastern Europe proved by alternative phylogenetic analysis. - Studia bot. hung. 46(2): 69-94. https://doi.org/10.17110/studbot.2015.46.2.69

Navarro-Rosinés, P., Etayo, J. and Breuss, O. (1996): Catapyrenium llimonae sp. nova y C. nuriense sp. nova (Verrucariaceae, liquenes), dos especies nuevas para la Península Ibérica. - Candollea 51: 139-145.

Prieto, M., Aragón, G. and Martínez, I. (2010): The genus Catapyrenium s. lat. (Verrucariaceae) in the Iberian Peninsula and the Balearic Islands. - Lichenologist 42(6): 637-684. https://doi.org/10.1017/s0024282910000319

Prieto, M., Martínez, I., Aragón, G., Gueidan, C. and Lutzoni, F. (2012): Molecular phylogeny of Heteroplacidium, Placidium, and related catapyrenioid genera (Verrucariaceae, lichen-forming Ascomycota). - Amer. J. Bot. 99(1): 23-35. https://doi.org/10.3732/ ajb.1100239 